\title{
Antiepileptic Medicinal Plants Used in Traditional Medicine to Treat Epilepsy
}

\author{
E. Ngo Bum et al. ${ }^{*}$ \\ ${ }^{1}$ Department of Biological Sciences, Faculty of Science, University of Ngaoundéré, \\ Ngaoundéré, \\ Cameroon
}

\section{Introduction}

Epilepsy is a disease that affects about 40 million people worldwide (Njamshi et al., 2010). In 1968, the prevalence of epilepsy in Africa was about 4.8 to $40 \%$. In 1996, Diop and collaborators reported in Senegal a prevalence of epilepsy of 21 \%o (Diop et al., 1996). In 2006, Ngoungou and collaborators estimated the prevalence in sub-Saharan Africa to be two or three time highest than the rate in developed world (Ngoungou et al., 2007). In Cameroon, some epidemiological studies on epilepsy have shown that, the prevalence of epilepsy is estimated to vary from 5-136/1000. The highest ones are reported in some villages of the Cameroon Central Province located in the Sanaga and Mbam River Valley (Nchoji Nkwi \& Tioko Ndonko, 1989; Dongmo et al., 2000; Preux et al., 2000; Boussinesq et al., 2002; Kamgno et al., 2003; Dongmo et al., 2004; Prischich et al., 2008). Cameroon is one of the countries most affected by epilepsy in Africa and in the world. Thus, epilepsy is among the major public health problems in Cameroon. In Africa and in Cameroon particularly, phytotherapy in traditional medicine still plays an important role in the management of diseases, mainly among populations with very low income (Geoffrey \& Kirby, 1996). And phytotherapy relies on the use of a wide variety of plant species. Annona muricata Linn (Annonaceae), Annona senegalensis Pers (Annonaceae), Bidens pilosa Linn (Asteraceae), Bryophyllum pinnatum (Lam) Oken (Crassulaceae), Citrus sinenis (Linn) Osbeck (Rutaceae), Clerodendron thomsoniae Balf (Verbenaceae), Daniellia oliveri (Rolfe) Hutch and Dalz (Caesalpiniaceae), Datura stramonium Linn (Solanaceae), Detarium microcarpum Guil et Perr (Caesalpiniaceae), Euphorbia hirta Linn (Euphorbiaceae), Flacourtia indica Willd (Flacourtiaceae), Hymenocardia acida Tul (Hymenocardiaceae), Jatropha gossypiifolia Linn (Euphorbiaceae), Khaya senegalensis A Juss (Desrousseaux) (Meliaceae), Mentha cordifolia Auct (Lamiaceae), Prosopis Africana Guill and Perr (Taub) (Mimosaceae), Ricinus communis Linn (Euphorbiaceae), Securidaca longepedunculata Fres (Polygalaceae), Senna singueana (Delile) Lock 1988 (Caesalpiniaceae), Terminalia glaucescens Planch. ex Benth (Combretaceae), Terminalia mollis Laws (Combretaceae), Tetrapleura tétraptera Taub (Schum Thonn)

\footnotetext{
${ }^{*}$ G.S. Taiwe ${ }^{2}$, F.C.O. Moto' ${ }^{1}$, G.T. Ngoupaye ${ }^{1}$, R.R.N. Vougat ${ }^{1}$, V.D. Sakoue ${ }^{1}$, C. Gwa ${ }^{1}$, E.R. Ayissi², C. Dong ${ }^{2}$, A. Rakotonirina ${ }^{2}$ and S.V. Rakotonirina ${ }^{2}$

1 Department of Biological Sciences, Faculty of Science, University of Ngaoundéré, Ngaoundéré, Cameroon 2 Department of Animal Biology and Physiology, Faculty of Sciences, University of Yaoundé 1, Yaoundé, Cameroon
} 
(Mimosaceae), Trichilia emetica Vahl (Meliaceae) and Vitellaria paradoxa C F Gaertn (Sapotaceae) are plants that are being used empirically in traditional medicine in Cameroon to treat epilepsy and diseases related to the brain like agitations, anxiety, convulsions, dizziness, headaches, insomnia, migraines, pains and schizophrenia according to our traditional Healers and the literature (Abbiw, 1990; Adjanohoun et al., 1984, 1996; Arbonnier, 2000; Berhaut, 1975; Biholong, 1986; Bouquet, 1969; Brenan, 1959; Dalziel, 1937; Hutchinson \& Dalziel, 1958; Iwu, 1993; Joyner, 2004; Malgras, 1992; Mutasa et al., 1990; Nwaiwu \& Akah, 1986; Pousset, 1989; Raponda-Walker \& Silans, 1961; Saulnier, 1998) (Table 1). Though the literature showed a lot of pharmacological studies done

\begin{tabular}{|c|c|c|c|c|c|c|}
\hline $\begin{array}{l}\text { Name of the } \\
\text { plant }\end{array}$ & $\begin{array}{l}\text { Part of the } \\
\text { plant used }\end{array}$ & $\begin{array}{c}\text { Form of } \\
\text { the } \\
\text { medicine }\end{array}$ & Diseases & $\begin{array}{c}\text { Chemical } \\
\text { characterization }\end{array}$ & $\begin{array}{c}\text { Pharmaco- } \\
\text { logical } \\
\text { properties }\end{array}$ & Country \\
\hline $\begin{array}{l}\text { Annona } \\
\text { muricata }\end{array}$ & Leaves & \begin{tabular}{|l|} 
Infusion \\
Decoction \\
\end{tabular} & \begin{tabular}{|l|} 
Insomnia, diabetes \\
Spasms, Fever
\end{tabular} & $\begin{array}{l}\text { Steroid, cardiac } \\
\text { glycosides }\end{array}$ & Antimicrobial & \begin{tabular}{|l|} 
Cameroon, \\
Forest areas
\end{tabular} \\
\hline $\begin{array}{l}\text { Annona } \\
\text { senegalensis }\end{array}$ & $\begin{array}{l}\text { Leaves } \\
\text { Roots }\end{array}$ & Infusion & $\begin{array}{l}\text { Convulsions, Epilepsy } \\
\text { Sterility, diarrhoea, } \\
\text { dysentery }\end{array}$ & & anticonvulsant & $\begin{array}{l}\text { Cameroon, } \\
\text { Central Africa } \\
\text { West Africa, } \\
\text { South Africa }\end{array}$ \\
\hline Bidens pilosa & Leaves & Decoction & $\begin{array}{l}\text { Dizziness, migraines, } \\
\text { headaches, rheumatism }\end{array}$ & & $\begin{array}{l}\text { Anti } \\
\text { hypertensive }\end{array}$ & \begin{tabular}{|l|} 
Cameroon, \\
Central \\
America \\
\end{tabular} \\
\hline $\begin{array}{l}\text { Bryophyllum } \\
\text { pinnatum }\end{array}$ & Leaves & \begin{tabular}{|l|} 
Applica- \\
tion on \\
head \\
Decoction
\end{tabular} & $\begin{array}{l}\text { Convulsions, rheumatism } \\
\text { Arthritis }\end{array}$ & $\begin{array}{l}\text { Flavonoids, } \\
\text { antraquinones }\end{array}$ & $\begin{array}{l}\text { Antinociceptive } \\
\text {, anti- } \\
\text { inflammatory } \\
\text { antidiabetic }\end{array}$ & Central Africa \\
\hline Citrus sinenis & $\begin{array}{l}\text { Leaves + } \\
\text { Flowers } \\
\text { Barks } \\
\text { Roots }\end{array}$ & $\begin{array}{l}\text { Decoction } \\
\text { Infusion }\end{array}$ & $\begin{array}{l}\text { Epilepsy, convulsions, } \\
\text { Insomnia, agitation } \\
\text { Headaches, Malaria fever } \\
\text { Anxiety, schizophrenia }\end{array}$ & & Sedative & $\begin{array}{l}\text { Humid } \\
\text { tropical areas }\end{array}$ \\
\hline $\begin{array}{l}\text { Clerodendron } \\
\text { thomsoniae }\end{array}$ & $\begin{array}{l}\text { Leaves } \\
\text { Roots }\end{array}$ & Decoction & $\begin{array}{l}\text { Convulsions, head aches } \\
\text { Parasitic diseases }\end{array}$ & & \begin{tabular}{|l|} 
effect on \\
purinergic \\
neurotransmissi \\
on
\end{tabular} & $\begin{array}{l}\text { Cameroon, } \\
\text { India }\end{array}$ \\
\hline $\begin{array}{l}\text { Daniellia } \\
\text { oliveri }\end{array}$ & $\begin{array}{l}\text { Barks } \\
\text { Roots }\end{array}$ & & $\begin{array}{l}\text { Epilepsy, Migraine, head } \\
\text { aches } \\
\text { Epilepsy, anxiety, } \\
\text { schizophrenia }\end{array}$ & & & $\begin{array}{l}\text { Angola, } \\
\text { Cameroon } \\
\text { Sudan, West } \\
\text { Africa Central } \\
\text { Africa } \\
\end{array}$ \\
\hline $\begin{array}{l}\text { Datura } \\
\text { stramonium }\end{array}$ & $\begin{array}{l}\text { Fruits } \\
\text { Leaves }\end{array}$ & & $\begin{array}{l}\text { Epilepsy } \\
\text { Coughs, asthma, pains }\end{array}$ & $\begin{array}{l}\text { Alkaloids, } \\
\text { atropine }\end{array}$ & & $\begin{array}{l}\text { Africa, Asia, } \\
\text { America, } \\
\text { Europa } \\
\end{array}$ \\
\hline $\begin{array}{l}\text { Detarium } \\
\text { microcarpum }\end{array}$ & $\begin{array}{l}\text { Leaves } \\
\text { Barks } \\
\text { Roots }\end{array}$ & Decoction & $\begin{array}{l}\text { Dizziness, schizophrenia, } \\
\text { paralysis malaria, diarrhoea } \\
\text { Epilepsy, Pains } \\
\text { Paralysis }\end{array}$ & & & $\begin{array}{l}\text { West Africa } \\
\text { Central Africa }\end{array}$ \\
\hline $\begin{array}{l}\text { Euphorbia } \\
\text { hirta }\end{array}$ & Whole plant & Decoction & $\begin{array}{l}\text { Convulsions, Insomnia } \\
\text { Diarrhoea, amoeba, asthma, } \\
\text { coughs, pains }\end{array}$ & $\begin{array}{l}\text { Alkaloids, } \\
\text { tannins }\end{array}$ & Anxiolytic & $\begin{array}{l}\text { Africa } \\
\text { continent }\end{array}$ \\
\hline $\begin{array}{l}\text { Flacourtia } \\
\text { indica }\end{array}$ & $\begin{array}{l}\text { Sterm barks } \\
\text { Fruts } \\
\text { Leaves }\end{array}$ & & $\begin{array}{l}\text { Epilepsy, headache, fever, } \\
\text { stomach-ache, diarrhoea } \\
\text { Sleep disorders }\end{array}$ & $\begin{array}{l}\text { beta-sistosterol } \\
\text { butyrolactone, } \\
\text { steroids, } \\
\text { flacourtine, } \\
\text { flavonoids, } \\
\text { coumarine, } \\
\text { terpenoids, } \\
\text { polyphenols }\end{array}$ & \begin{tabular}{|l|} 
Antiplasmodial \\
Protection \\
against liver \\
toxicity
\end{tabular} & \\
\hline
\end{tabular}




\begin{tabular}{|c|c|c|c|c|c|c|}
\hline $\begin{array}{c}\text { Name of the } \\
\text { plant }\end{array}$ & $\begin{array}{l}\text { Part of the } \\
\text { plant used }\end{array}$ & $\begin{array}{c}\text { Form of } \\
\text { the } \\
\text { medicine }\end{array}$ & Diseases & $\begin{array}{c}\text { Chemical } \\
\text { characterization }\end{array}$ & $\begin{array}{l}\text { Pharmaco- } \\
\text { logical } \\
\text { properties }\end{array}$ & Country \\
\hline $\begin{array}{l}\text { Hymenocardia } \\
\text { acida }\end{array}$ & $\begin{array}{l}\text { Leaves } \\
\text { Barks } \\
\text { Roots }\end{array}$ & $\begin{array}{l}\text { Infusion } \\
\text { Powder }\end{array}$ & $\begin{array}{l}\text { Headaches, fever, } \\
\text { hypotension, diabetes, sickle } \\
\text { cells } \\
\text { Epilepsy, schizophrenia }\end{array}$ & & & $\begin{array}{l}\text { Cameroon, } \\
\text { Central Africa } \\
\text { West Africa }\end{array}$ \\
\hline $\begin{array}{l}\text { Jatropha } \\
\text { gossypiifolia }\end{array}$ & \begin{tabular}{|l|} 
Leaves + \\
Roots \\
Roots \\
\end{tabular} & & $\begin{array}{l}\text { Convulsions, fever, } \\
\text { hypertension } \\
\text { Convulsions, }\end{array}$ & & & $\begin{array}{l}\text { Cameroon, } \\
\text { Central Africa, } \\
\text { West Africa } \\
\end{array}$ \\
\hline $\begin{array}{l}\text { Khaya } \\
\text { senegalensis }\end{array}$ & $\begin{array}{l}\text { Leaves, Barks } \\
\text { Roots }\end{array}$ & Decoction & $\begin{array}{l}\text { Headaches, schizophrenia, } \\
\text { malaria } \\
\text { Fever }\end{array}$ & \begin{tabular}{|l|} 
Saponins, \\
tannins, \\
triterpenes \\
\end{tabular} & $\begin{array}{l}\text { Antiinflamm- } \\
\text { atory }\end{array}$ & Cameroon \\
\hline $\begin{array}{l}\text { Mentha } \\
\text { cordifolia }\end{array}$ & Leaves & Infusion & Insomnia, muscle relaxant, & & Antioxydant & Cameroon \\
\hline $\begin{array}{l}\text { Prosopis } \\
\text { Africana }\end{array}$ & $\begin{array}{l}\text { Leaves } \\
\text { Barks }\end{array}$ & Decoction & $\begin{array}{l}\text { Epilepsy, insomnia, anxiety } \\
\text { states, headaches, migraine, } \\
\text { agitation, fever } \\
\text { Vermifuge, fever }\end{array}$ & & $\begin{array}{l}\text { Antitrypano- } \\
\text { somal }\end{array}$ & $\begin{array}{l}\text { Cameroon } \\
\text { West Africa }\end{array}$ \\
\hline $\begin{array}{l}\text { Ricinus } \\
\text { communis }\end{array}$ & $\begin{array}{l}\text { Leaves }+ \\
\text { flowers }\end{array}$ & \begin{tabular}{|l|} 
Decoction \\
\end{tabular} & \begin{tabular}{|l|} 
Epilepsy, convulsions, \\
headaches, diarrhea, asthma
\end{tabular} & ricin & $\begin{array}{l}\text { Neuroleptic like } \\
\text { properties }\end{array}$ & $\begin{array}{l}\text { Central Africa, } \\
\text { West Africa } \\
\end{array}$ \\
\hline $\begin{array}{l}\text { Securidaca } \\
\text { longepeduncul } \\
\text { ata }\end{array}$ & \begin{tabular}{|l|} 
Barks \\
Roots, Leaves
\end{tabular} & & \begin{tabular}{|l|} 
Epilepsy, schizophrenia \\
Pains, Rheumatisms
\end{tabular} & & Anxiolytic & $\begin{array}{l}\text { Central Africa, } \\
\text { West Africa }\end{array}$ \\
\hline $\begin{array}{l}\text { Senna } \\
\text { singueana }\end{array}$ & $\begin{array}{l}\text { Leaves } \\
\text { Leaves and } \\
\text { flowers } \\
\text { Barks and } \\
\text { Roots, }\end{array}$ & & $\begin{array}{l}\text { Fever, } \\
\text { Conjunctivitis, } \\
\text { Convulsions, gonorrhoea, } \\
\text { bilharzias, stomach-aches, } \\
\text { constipation, } \\
\text { Epilepsy, syphilis, } \\
\end{array}$ & $\begin{array}{l}\text { 7-Methylphyscion } \\
\text { Cassiamin A }\end{array}$ & & $\begin{array}{l}\text { Cameroon, } \\
\text { Mali, Soudan, } \\
\text { East and } \\
\text { South Africa. }\end{array}$ \\
\hline $\begin{array}{l}\text { Terminalia } \\
\text { glaucescens, }\end{array}$ & $\begin{array}{l}\text { Leaves } \\
\text { Barks } \\
\text { Roots }\end{array}$ & \begin{tabular}{|l|} 
Decoction \\
Decoction \\
Macera- \\
tion
\end{tabular} & $\begin{array}{l}\text { Malaria, stomach-aches, } \\
\text { leucorrhoea, Hepatitis, } \\
\text { leucorrhoea } \\
\text { Epilepsy, diarrhoea, } \\
\text { leucorrhoea }\end{array}$ & $\begin{array}{l}\text { Terminalin A } \\
\text { Glaucinoic Acid }\end{array}$ & antimicrobial & \\
\hline $\begin{array}{l}\text { Terminalia } \\
\text { mollis }\end{array}$ & Roots & & Epilepsy & & & Central Africa, \\
\hline $\begin{array}{l}\text { Tetrapleura } \\
\text { tétraptera }\end{array}$ & $\begin{array}{l}\text { Barks } \\
\text { Fruits } \\
\text { Roots }\end{array}$ & Decoction & $\begin{array}{l}\text { Epilepsy } \\
\text { Convulsions } \\
\text { Fevers, malaria }\end{array}$ & Saponins, tannins & Anticonvulsant & \begin{tabular}{|l|} 
Angola, \\
Cameroon, \\
Sudan, West \\
Africa, Central \\
Africa \\
\end{tabular} \\
\hline $\begin{array}{l}\text { Trichilia } \\
\text { emetica }\end{array}$ & $\begin{array}{l}\text { Roots } \\
\text { Barks }\end{array}$ & & $\begin{array}{l}\text { Epilepsy, anti-parasitic } \\
\text { diseases } \\
\text { Head aches }\end{array}$ & Tannins, sterols & & $\begin{array}{l}\text { Savannah belt, } \\
\text { open } \\
\text { woodland in } \\
\text { Africa }\end{array}$ \\
\hline $\begin{array}{l}\text { Vitelaria } \\
\text { paradoxa }\end{array}$ & $\begin{array}{l}\text { Leaves } \\
\text { Leaves + } \\
\text { Barks }\end{array}$ & Decoction & $\begin{array}{l}\text { Convulsions, Epilepsy, } \\
\text { headaches, stress } \\
\text { Head aches }\end{array}$ & \begin{tabular}{|l} 
Saponins, \\
alkaloids, \\
tannins, cadiac \\
glycosides \\
\end{tabular} & Antimicrobial & $\begin{array}{l}\text { Cameroon, } \\
\text { Brazil }\end{array}$ \\
\hline
\end{tabular}

Table 1. Parts of the plant, form of the medicine and diseases treated in traditional medicine. Adeyemi et al., 2010; Adjanohoum et al., 1984; Adjanouhoun et al., 1996; Adzu et al., 2003; Agassounon et al. 2008; Anete et al., 1998 ; Anuradha et al., 2008; Arbonnier, 2000; Berhaut, 1975; Brenan, 1959 ; Dimo et al., 2002; El-Mahmood et al., 2008; Ezugwu \& Odoh, 2003; Gusman-Gutierez \& Navarrete, 2009; Iwu, 1993; Joyner, 2004; Lompo et al., 1998; Malgras, 1992; Mutasa et al., 1990; Nazneen et al., 2009; Ogundiya, 2009; Ojewole, 2005; Palgrave, 2003; Pathak et al., 2010; Pousset, 1989; Satyarayana et al., 1996; Sunday et al., 2009; Saulnier, 1998; Seema Zareen, 2006; Worapan et al., 2009. 
with these plants, very few were done to study their sedative and anticonvulsant properties. This study was undertaken to evaluate the anticonvulsant and sedative properties of these plants used in the treatment of insomnia and epilepsy in traditional medicine in Africa, particularly in Cameroon.

\section{Materials and methods}

\subsection{Animals}

Adult male mice (Mus musculus Swiss; $22 \pm 2$ g; 6 or 8 per group) were used for this study. The animals were housed in standard cages at $25^{\circ} \mathrm{C}$, on a $12 / 12 \mathrm{~h}$ light-dark cycle. They were supplied with food and water ad libitum.

Drugs were administered in a volume of $10 \mathrm{ml} / \mathrm{kg}$ of mice body weight. The study was conducted in accordance with the nationally ( $\mathrm{N}^{\circ}$.FWA-IRB00001954) and internationally accepted principles for laboratory animal use and care. In diazepam or sodium thiopentalinduced sleep tests, mice were divided into negative control group that received distilled water and four test groups that received different doses of the plant extracts. In anticonvulsant tests, there was one more group that received a known anticonvulsant compound and served as a positive control.

\subsection{Plant material}

A voucher specimen of each plant was authenticated by a botanist, Professor Mapongmetsem Pierre Marie, Department of Biological Sciences, University of Ngaoundéré and deposited at the National Herbarium of Cameroon in Yaoundé.

\subsection{Preparation of the extracts}

\subsubsection{Decoction}

$10 \mathrm{~g}$ of each plant material were macerated for $1 \mathrm{~h}$ in an amount of distilled water $(25,50$, 75,100 or $150 \mathrm{ml}$ ) according to the plant. The mixture was boiled for $20 \mathrm{~min}$. After cooling, the supernatant (decoction) was collected and filtered. The decoction of each plant was diluted in distilled water to obtain less concentrated solutions. In another experiment, the decoction was dried and the $\mathrm{w} / \mathrm{w}$ yield of the extract was calculated (table 2). The decoctions were prepared according to the methods close to the ones used in traditional medicine.

\subsubsection{Maceration}

$10 \mathrm{~g}$ of dried fruits of Datura stramonium were macerated in $50 \mathrm{ml}$ of distilled water. After 1 $\mathrm{h}$ the supernatant was collected, filtered and used in mice. The $\mathrm{w} / \mathrm{w}$ yield of the extract was obtained (table 2).

\subsection{Anticonvulsant tests}

\subsubsection{N-methyl-D-aspartate (NMDA) test}

Six groups of 6 or 8 mice received different treatments. Group I (negative control) was treated with distilled water. Groups II to V (test groups) were treated with 4 doses of the plant extracts. Group VI (positive control) was treated with $3 \mathrm{mg} / \mathrm{kg}$ of CGP 37849 i.p. or $33 \mathrm{nmol} / \mathrm{kg}$ of D-AP7 i.p. Mice were injected subcutaneously with NMDA, $75 \mathrm{mg} / \mathrm{kg} 1 \mathrm{~h}$ after administration of the different treatments. They were observed for $30 \mathrm{~min}$. Animals 
that did not exhibit turning behaviour within the $30 \mathrm{~min}$ of observation were declared protected. Turning behaviour was characterised by two consecutive $360^{\circ}$ cycles fulfilled by the same animal (Croucher et al., 1982; Ngo Bum et al., 2001; 2009a; 2009b; Schmutz et al., 1990).

\subsubsection{Strychnine (STR) test}

Six groups of 6 or 8 mice received different treatments as above, except that group VI (positive control) was treated with clonazepam $(3 \mathrm{mg} / \mathrm{kg}$, i.p.). Convulsions followed by death were induced in mice by the i.p. injection of $2.5 \mathrm{mg} / \mathrm{kg}$ STR nitrate $1 \mathrm{~h}$ after administration of the different treatments. The animals which survived more than $10 \mathrm{~min}$ after strychnine injection were qualified protected (Ngo Bum et al., 2001, 2009a).

\subsubsection{Picrotoxine (PIC) test}

Six groups of 6 or 8 mice received different treatments as above, except that group VI (positive control) was treated with clonazepam $(0.4 \mathrm{mg} / \mathrm{kg}$, i.p.). Clonic seizures were induced in mice by the i.p. injection of $7.5 \mathrm{mg} / \mathrm{kg}$ PIC $1 \mathrm{~h}$ after administration of the different treatments. The animals which did not convulse within the $15 \mathrm{~min}$ of observation after PIC injection were qualified protected (Lehmann et al., 1988; Ngo Bum et al., 2001).

\subsubsection{Pentylenetetrazol (PTZ) test}

Six groups of 6 or 8 mice received different treatments as above, except that group VI (positive control) was treated with clonazepam $(0.1 \mathrm{mg} / \mathrm{kg}$, i.p.). Clonic seizures were induced in mice by the i.p. injection of $70 \mathrm{mg} / \mathrm{kg}$ PTZ $1 \mathrm{~h}$ after administration of the different treatments. The animals that did not convulse within the $10 \mathrm{~min}$ from the injection of PTZ were qualified protected (Ngo Bum et al., 2001, 2009a, 2009b).

\subsubsection{Isonicotinic hydrazide acid (INH) test}

Six groups of 6 or 8 mice received different treatments as above, except that group VI (positive control) was treated with diazepam, $10 \mathrm{mg} / \mathrm{kg}$ (per os). Animals were injected i.p. with INH $250 \mathrm{mg} / \mathrm{kg} 1 \mathrm{~h}$ after the administration of the different treatments. The time to the onset of clonic or tonic seizures was recorded. (Bernasconi et al., 1988; Ngo Bum et al., 2001).

\subsection{Diazepam or sodium thiopental-induced sleep in mice}

Five groups of 6 or 8 mice received different treatments. Group I (negative control) was treated with distilled water and groups II to V (test groups) were treated with 4 doses of the plant extracts.The methods described by Beretz et al., (1978) and modified by Rakotonirina et al., (2001) were used. Sleep potentiating effects of the plant were studied in mice that received sodium thiopental or diazepam at a dose of $50 \mathrm{mg} / \mathrm{kg}$ (i.p.) 1 hour after the administration of the different treatments. The time between the loss of the straightening reflex and the regain of this reflex measured the sleeping time. The loss or the regain of the straightening reflex was measured by stimulating the external ear. When the mouse anterior paw does not move after stimulation with horsehair, the animal is sleeping. When the mouse is awakened, it moves and shakes its paw. 


\begin{tabular}{|c|c|c|c|c|c|}
\hline Name of the plant & $\begin{array}{l}\text { Part of the } \\
\text { plant used }\end{array}$ & $\begin{array}{c}\text { Quantity } \\
\text { plant powder } \\
\text { (g) }\end{array}$ & $\begin{array}{l}\text { Quantity of } \\
\text { water (ml) }\end{array}$ & $\begin{array}{l}\text { Yield } \\
(\%)\end{array}$ & $\begin{array}{c}\text { Root of } \\
\text { administra- } \\
\text { tion }\end{array}$ \\
\hline Annona muricata & Fresh leaves & 10 & 50 & 6 & i.p. \\
\hline Annona senegalensis & Dried leaves & 10 & 75 & 5 & i.p. \\
\hline Bidens pilosa & Fresh leaves & 10 & 25 & 3.5 & i.p. \\
\hline Bryophyllum pinnatum & Fresh leaves & 10 & 25 & 7 & i.p. \\
\hline Citrus sinenis & Fresh leaves & 10 & 50 & 5 & i.p. \\
\hline Clerodendron thomsoniae & Dried leaves & 10 & 50 & 6.7 & i.p. \\
\hline Daniellia oliveri & Dried barks & 10 & 50 & 9.9 & p.o. \\
\hline Datura stramonium & Dried fruits & 10 (macerate) & 50 & 7 & i.p. \\
\hline Detarium microcarpum & Dried roots & 10 & 50 & 7.43 & p.o. \\
\hline Euphorbia hirta & Fresh plant & 10 & 50 & 7 & i.p. \\
\hline Flacourtia indica & Dried barks & 10 & 100 & 10 & p.o. \\
\hline Hymenocardia acida & Fresh leaves & 10 & 25 & 2.19 & i.p. \\
\hline Jatropha gossypiifolia & Dried leaves & 10 & 50 & 7 & i.p. \\
\hline Khaya senegalensis & Dried leaves & 10 & 75 & 5 & i.p. \\
\hline Mentha cordifolia & Fresh leaves & 10 & 50 & 7 & i.p. \\
\hline Prosopis Africana & Dried leaves & 10 & 50 & 5.6 & i.p. \\
\hline Ricinus communis & Fresh leaves & 10 & 50 & 6 & p.o. \\
\hline $\begin{array}{l}\text { Securidaca } \\
\text { longepedunculata }\end{array}$ & Dried roots & 10 & 150 & 10 & i.p. \\
\hline Senna singueana & Dried roots & 10 & 50 & 8 & p.o. \\
\hline Terminalia glaucescens & Dried roots & 10 & 100 & 7.6 & p.o. \\
\hline Terminalia mollis & Dried roots & 10 & 50 & 7.1 & p.o. \\
\hline Tetrapleura tétraptera & Dried barks & 10 & 50 & 4.2 & i.p. \\
\hline Trichilia emetic & Fresh roots & 10 & 50 & 6.3 & p.o. \\
\hline Vitelaria paradoxa & Fresh leaves & 10 & 150 & 12.6 & i.p. \\
\hline
\end{tabular}

i.p. (intraperitoneal), p.o. (per os).

Table 2. Quantities of plants powder and distilled water, and part of the plant used to prepare the decoctions.

\subsection{Statistical analysis}

Three parameters were measured: the protection against chemically-induced seizures, the latency to the onset of seizures (min) in INH test, the latency to the onset of sleep and the sleeping time $(\mathrm{min})$ in the sleep potentiation test. Data of the control groups were compared to data of groups treated with the plants extracts and to data of the positive control groups. The statistical analysis were done using Fisher exact test and Anova followed by Dunnett (REGWQ). P<0.05 was considered significant.

\subsection{Chemicals}

D-2-amino-7-phosphonoheptanoate, Clonazepam, Isonicotinic hydrazide acid, N-methyl-Daspartate, penthylenetetrazol, picrotoxine, sodium thiopental and strychnine are from Sigma Chemical, USA. Diazepam is from Roche, France. 


\section{Results}

\subsection{Sedative properties}

The extracts of twenty one plants increased in a dose-dependent manner the sleeping time induced by sodium thiopental or diazepam. The most potent was Datura stramonium. it multiplied by a factor of 5 the sleeping time of the control group (from $16 \pm 7$ to $94 \pm 25 \mathrm{~min}$ at a dose of $70 \mathrm{mg} / \mathrm{kg}$ ), but this extract was very toxic for animals. The decoctions of eight plants multiplied by a factor of 4 the sleeping time of their control group: Annona senegalensis (from $19 \pm 4$ to $89 \pm 29 \mathrm{~min}$ at a dose of $67 \mathrm{mg} / \mathrm{kg}$ ), Clerodendron thomsoniae (from $19 \pm 3$ to $94 \pm 30 \mathrm{~min}$ at a dose of $134 \mathrm{mg} / \mathrm{kg}$ ), Daniellia oliveri (from $20 \pm 8$ to $81 \pm 13 \mathrm{~min}$ at a dose of $198 \mathrm{mg} / \mathrm{kg}$ ), Hymenocardia acida (from $20 \pm 11$ to $85 \pm 21 \mathrm{~min}$ at a dose of 87.6 $\mathrm{mg} / \mathrm{kg}$ ), Securidaca longepedunculata (from $18 \pm 3$ to $78 \pm 14 \mathrm{~min}$ at a dose of $66.7 \mathrm{mg} / \mathrm{kg}$ ), Terminalia mollis (from $17 \pm 1$ to $84 \pm 15 \mathrm{~min}$ at a dose of $70 \mathrm{mg} / \mathrm{kg}$ ), Tetrapleura tetraptera (from $19 \pm 3$ to $91 \pm 15 \mathrm{~min}$ at a dose of $84 \mathrm{mg} / \mathrm{kg}$ ) and Trichilia emetica (from $17 \pm 1$ to $84 \pm 10$ min at a dose of $126 \mathrm{mg} / \mathrm{kg}$ ). The sleeping time of the control groups were multiplied by a factor of 3 by six plants: Flacourtia indica (from $16 \pm 12$ to $49 \pm 3 \mathrm{~min}$ at a dose of $100 \mathrm{mg} / \mathrm{kg}$ ), Jatropha gossypiifolia (from $11 \pm 5$ to $43 \pm 15 \mathrm{~min}$ at a dose of $140 \mathrm{mg} / \mathrm{kg}$ ), Prosopis Africana (from $19 \pm 3$ to $61 \pm 26 \mathrm{~min}$ at a dose of $112 \mathrm{mg} / \mathrm{kg}$ ), Senna singueana (from $24 \pm 2$ to $86 \pm 5$ min at a dose of $20 \mathrm{mg} / \mathrm{kg}$ ), Terminalia glaucescens (from $37 \pm 13$ to $120 \pm 21 \mathrm{~min}$ at a dose of $76 \mathrm{mg} / \mathrm{kg}$ ), and Vitellaria paradoxa (from $25 \pm 4$ to $84 \pm 20 \mathrm{~min}$ at a dose of $84 \mathrm{mg} / \mathrm{kg}$ ). The decoctions of five plants multiplied by a factor of 2 the sleeping time of their control group: Annona muricata (from $31 \pm 11$ to $71 \pm 15 \mathrm{~min}$ at a dose of $120 \mathrm{mg} / \mathrm{kg}$ ), Bidens pilosa (from 31 \pm 2 to $80 \pm 2 \mathrm{~min}$ at a dose of $140 \mathrm{mg} / \mathrm{kg}$ ), Detarium microcarpum (from $20 \pm 6$ to $52 \pm 12 \mathrm{~min}$ at a dose of $111.45 \mathrm{mg} / \mathrm{kg}$ ), Euphorbia hirta (from $56 \pm 16$ to $145 \pm 10 \mathrm{~min}$ at a dose of 140 $\mathrm{mg} / \mathrm{kg}$ ) and Mentha cordifolia (from $10 \pm 2$ to $24 \pm 3 \mathrm{~min}$ at a dose of $140 \mathrm{mg} / \mathrm{kg}$ ). Bryophyllum pinnatum induced a slight increase of the sleeping time. Only Citrus sinenis and Kaya senegalensis could not increase the total sleep time of mice (table 3). Some of those plants also reduced the onset time of sleep (Table 4).

\subsection{Anticonvulsant properties}

\subsubsection{On PTZ- induced convulsions}

$78.3 \%$ of plants extract were effective against PTZ-induced convulsions. Annona muricata, Annona senegalensis, Bidens pilosa, Clerodendron thomsoniae, Daniellia oliveri, Datura stramonium, Detarium microcarpum, Euphorbia hirta, Flacourtia indica, Hymenocardia acida, Mentha cordifolia, Ricinus communis, Securidaca longepedunculata, Senna singueana, Terminalia glaucescens, Terminalia mollis, Tetrapleura tétraptera, Trichilia emetica and Vitellaria paradoxa protected mice against convulsions induced by PTZ (table 5).

\subsubsection{On STR- induced convulsions}

The percentage of plants extracts that protected mice against STR-induced convulsions was $77.8 \%$. Annona muricata, Bidens pilosa, Daniellia oliveri, Detarium microcarpum, Flacourtia indica, Hymenocardia acida, Jatropha gossypiifolia, Khaya senegalensis, Mentha cordifolia, Prosopis Africana, Securidaca longepedunculata, Senna singueana, Terminalia mollis, Trichilia emetica protected mice against STR- induced convulsions (table 5).

\subsubsection{On PIC- induced convulsions}

The percentage of plants extracts that protected mice against PIC-induced convulsions was 87.5\%. Clerodendron thomsoniae, Flacourtia indica, Mentha cordifolia, Securidaca longepedunculata, 
Senna singueana, Terminalia glaucescens and Vitellaria paradoxa protected mice against convulsions induced by PIC (table 5).

\begin{tabular}{|c|c|c|c|c|c|c|}
\hline & & & & Doses o & nts in $\mathrm{mg}$ & \\
\hline Daniellia & & $\mathrm{CON}$ & 49.5 & 99 & 148.5 & 198 \\
\hline oliveri & DIAZ & $9 \pm 3$ & $6 \pm 1$ & $6 \pm 1$ & $5 \pm 2$ & $3 \pm 1^{* *}$ \\
\hline Detarium & & CON & 37.15 & 47.3 & 111.45 & 148.6 \\
\hline microcarpum & DIAZ & $9 \pm 3$ & $7 \pm 2$ & $6 \pm 3$ & $4 \pm 2^{*}$ & $6 \pm 3$ \\
\hline Flacourtia & & CON & 10 & 25 & 50 & 100 \\
\hline indica & DIAZ & $4 \pm 2$ & $8 \pm 6$ & $4 \pm 4$ & $11 \pm 6$ & $4 \pm 4$ \\
\hline Hymenocardia & & CON & 8.7 & 21.9 & 43.8 & 87.6 \\
\hline acida & DIAZ & $9 \pm 3$ & $7 \pm 3$ & $6 \pm 1^{*}$ & $5 \pm 1^{* *}$ & $3 \pm 1^{* * *}$ \\
\hline Mentha & & CON & 14 & 35 & 70 & 140 \\
\hline cordifolia & DIAZ & $3 \pm 1$ & $2 \pm 1$ & $2 \pm 1$ & $6 \pm 3$ & $4 \pm 1$ \\
\hline Securidaca & & CON & 10 & 20 & 50 & 66.7 \\
\hline longepedunculata & DIAZ & $6 \pm 1$ & $5 \pm 1$ & $5 \pm 1$ & $4 \pm 1^{*}$ & $4 \pm 1^{*}$ \\
\hline Senna & & CON & 20 & 40 & 80 & 160 \\
\hline singueana & DIAZ & $15 \pm 3$ & $6 \pm 1^{* * *}$ & $6 \pm 1^{* * *}$ & $7 \pm 1^{* * *}$ & $8 \pm 1^{* * *}$ \\
\hline Terminalia & & CON & 9.5 & 19 & 38 & 76 \\
\hline glaucescens & DIAZ & $4 \pm 2$ & $7 \pm 4$ & $5 \pm 1$ & $6 \pm 3$ & $2 \pm 2$ \\
\hline Terminalia & & $\mathrm{CON}$ & 14 & 35 & 70 & 140 \\
\hline mollis & DIAZ & $7 \pm 2$ & $5 \pm 1$ & $2 \pm 1^{* *}$ & $3 \pm 1^{* *}$ & $4 \pm 1^{*}$ \\
\hline Trichilia & & CON & 12.6 & 33 & 66 & 126 \\
\hline emetica & DIAZ & $6 \pm 1$ & $5 \pm 1$ & $4 \pm 1^{* * *}$ & $2 \pm 1^{* * *}$ & $2 \pm 1^{* * *}$ \\
\hline
\end{tabular}

Data represent the onset time of sleep time. Values are means \pm ESM. $N=6$ or 8 per dose, ${ }^{*}<p$ $0.05,{ }^{* *}<p$ $0.01,{ }^{* * *}<\mathrm{p} 0.001$ vs control, Anova followed by Dunnett $(\mathrm{REGWQ}) . \mathrm{CON}=$ distilled water, DIAZ $=$ diazepam $50 \mathrm{mg} / \mathrm{kg}$.

Table 3. The effects of the different plants on the onset time of sleep induced in mice by sodium thiopental or diazepam.

\subsubsection{On NMDA- induced turning behaviour}

The percentage of plants extracts that protected mice against NMDA-induced turning behaviour was $100 \%$. Annona muricata, Bidens pilosa, Bryophyllum pinnatum, Citrus sinenis, Euphorbia hirta, Khaya senegalensis protected mice against turning behaviour induced by NMDA (table 5).

\subsubsection{On MES- induced convulsions}

The percentage of plants extracts that protected mice against MES-induced convulsions was $25 \%$. Securidaca longepedunculata protected mice against convulsions induced by MES (table 5).

\subsubsection{On INH- induced convulsions}

The percentage of plants extracts that were effective against INH-induced convulsions in mice was $60 \%$. Ricinus communis, Securidaca longepedunculata, Senna singueana delayed the onset of seizures in INH test (table 5).

\subsubsection{Plants efficacy}

Flacourtia indica, Ricinus communis, Securidaca longepedunculata, Senna singueana, Terminalia glaucescens showed very good anticonvulsant activities (80 to 100\% of protection against PTZ, PIC or INH induced seizures). The other eighteen plants tested protected 50 to $75 \%$ of 
Doses of the plants in $\mathrm{mg} / \mathrm{kg}$

\begin{tabular}{|c|c|c|c|c|c|c|}
\hline $\begin{array}{l}\text { Annona } \\
\text { muricata }\end{array}$ & DIAZ & $\begin{array}{l}\text { CON } \\
31 \pm 11\end{array}$ & $\begin{array}{l}12 \\
51 \pm 26^{*}\end{array}$ & $\begin{array}{l}30 \\
67 \pm 6^{* * *}\end{array}$ & $\begin{array}{l}60 \\
68 \pm 2^{* * *}\end{array}$ & $\begin{array}{l}120 \\
71 \pm 15^{\star * *}\end{array}$ \\
\hline Annona & & CON & 6.7 & 17 & 34 & 67 \\
\hline senegalensis & DIAZ & $19 \pm 4$ & $52 \pm 18^{* * *}$ & $72 \pm 17^{\star * *}$ & $79 \pm 25^{* * *}$ & $89 \pm 29^{* * *}$ \\
\hline Bidens & & $\mathrm{CON}$ & 14 & 35 & 70 & 140 \\
\hline pilosa & DIAZ & $31 \pm 2$ & $70 \pm 2^{* * *}$ & $66 \pm 3^{* * *}$ & $79 \pm 5^{* * *}$ & $80 \pm 2^{* * *}$ \\
\hline Bryophyllum & & $\mathrm{CON}$ & 28 & 70 & 140 & 280 \\
\hline pinnatum & DIAZ & $21 \pm 2$ & $32 \pm 5^{* *}$ & $26 \pm 5$ & $35 \pm 1^{* *}$ & $31 \pm 6^{*}$ \\
\hline Citrus & & CON & 10 & 25 & 50 & 100 \\
\hline sinenis & DIAZ & $56 \pm 24$ & $50 \pm 20$ & $40 \pm 10$ & $45 \pm 12$ & $57 \pm 10$ \\
\hline Clerodendron & & CON & 13.4 & 33.5 & 67 & 134 \\
\hline thomsoniae & DIAZ & $19 \pm 3$ & $39 \pm 9^{* * *}$ & $74 \pm 22^{* * *}$ & $90 \pm 16^{* * *}$ & $94 \pm 30^{* * *}$ \\
\hline Daniellia & & CON & 49.5 & 99 & 148.5 & 198 \\
\hline oliveri & DIAZ & $20 \pm 8$ & $50 \pm 3^{* * *}$ & $74 \pm 8^{* * *}$ & $74 \pm 7^{* * *}$ & $81 \pm 13^{* * *}$ \\
\hline Datura & & $\mathrm{CON}$ & 3.5 & 7 & 35 & 70 \\
\hline stramonium & THIO & $16 \pm 7$ & $55 \pm 15^{\star * *}$ & $63 \pm 21^{* * *}$ & $85 \pm 23^{* * *}$ & $94 \pm 25^{* * *}$ \\
\hline Detarium & & $\mathrm{CON}$ & 37.15 & 47.3 & 111.45 & 148.6 \\
\hline microcarpum & DIAZ & $20 \pm 6$ & $38 \pm 10^{* *}$ & $46 \pm 13^{* *}$ & $52 \pm 12^{* * *}$ & $45 \pm 9^{* * *}$ \\
\hline Euphorbia & & CON & 14 & 35 & 70 & 140 \\
\hline hirta & DIAZ & $56 \pm 16$ & $99 \pm 24^{* *}$ & $97 \pm 21^{* *}$ & $117 \pm 26^{* * *}$ & $145 \pm 10^{* * *}$ \\
\hline Flacourtia & & CON & 10 & 25 & 50 & 100 \\
\hline indica & DIAZ & $16 \pm 12$ & $15 \pm 11$ & $38 \pm 25^{*}$ & $44 \pm 4^{* * *}$ & $49 \pm 3^{* * *}$ \\
\hline Hymenocardia & & CON & 8.7 & 21.9 & 43.8 & 87.6 \\
\hline acida & DIAZ & $20 \pm 11$ & $51 \pm 12^{* * *}$ & $70 \pm 15^{\star * *}$ & $77 \pm 23^{* * *}$ & $85 \pm 21^{* * *}$ \\
\hline Jatropha & & $\mathrm{CON}$ & 14 & 35 & 70 & 140 \\
\hline gossypiifolia & DIAZ & $11 \pm 5$ & $29 \pm 14^{*}$ & $27 \pm 13^{*}$ & $32 \pm 10^{* * *}$ & $43 \pm 15^{\star * *}$ \\
\hline Kaya & & $\mathrm{CON}$ & 6.7 & 17 & 34 & 67 \\
\hline senegalensis & DIAZ & $63 \pm 15$ & $52 \pm 21$ & $58 \pm 25$ & $58 \pm 23$ & $61 \pm 23$ \\
\hline Mentha & & CON & 14 & 35 & 70 & 140 \\
\hline cordifolia & DIAZ & $10 \pm 2$ & $16 \pm 5^{*}$ & $21 \pm 5^{* *}$ & $21 \pm 4^{* *}$ & $24 \pm 3^{* *}$ \\
\hline Prosopis & & CON & 11.2 & 28 & 56 & 112 \\
\hline africana & DIAZ & $19 \pm 3$ & $52 \pm 26^{*}$ & $57 \pm 17^{* *}$ & $31 \pm 17$ & $61 \pm 26^{* * *}$ \\
\hline Securidaca & & CON & 10 & 20 & 50 & 66.7 \\
\hline longepedunculata & DIAZ & $18 \pm 3$ & $60 \pm 27^{* *}$ & $65 \pm 14^{* * *}$ & $67 \pm 27^{* *}$ & $78 \pm 14^{* * *}$ \\
\hline Senna & & CON & 20 & 40 & 80 & 160 \\
\hline singueana & DIAZ & $24 \pm 2$ & $86 \pm 5^{\star *}$ & $77 \pm 3^{\star \star *}$ & $44 \pm 7^{* *}$ & $29 \pm 9 * * *$ \\
\hline Terminalia & & CON & 9.5 & 19 & 38 & 76 \\
\hline glaucescens & DIAZ & $37 \pm 13$ & $31 \pm 15$ & $79 \pm 40^{*}$ & $86 \pm 17^{* * *}$ & $120 \pm 21^{* * *}$ \\
\hline Terminalia & & CON & 14 & 35 & 70 & 140 \\
\hline mollis & DIAZ & $17 \pm 1$ & $44 \pm 7^{* * *}$ & $64 \pm 11^{* * *}$ & $84 \pm 15^{* * *}$ & $73 \pm 8^{* * *}$ \\
\hline Tetrapleura & & CON & 8.4 & 21 & 42 & 84 \\
\hline tétraptera & DIAZ & $19 \pm 3$ & $39 \pm 10^{* *}$ & $67 \pm 18^{* * *}$ & $82 \pm 14^{* * *}$ & $91 \pm 15^{* * *}$ \\
\hline Trichilia & & $\mathrm{CON}$ & 12.6 & 33 & 66 & 126 \\
\hline emetica & DIAZ & $17 \pm 1$ & $22 \pm 2^{*}$ & $29 \pm 4^{* *}$ & $71 \pm 7^{* * *}$ & $84 \pm 10^{* * *}$ \\
\hline Vitelaria & & CON & 12 & 21 & 42 & 84 \\
\hline paradoxa & DIAZ & $25 \pm 4$ & $40 \pm 13^{* * *}$ & $57 \pm 6^{* * *}$ & $59 \pm 8^{* * *}$ & $84 \pm 20^{* * *}$ \\
\hline
\end{tabular}

Data represent the total sleep time. Values are means \pm ESM. $N=6$ or 8 per dose, ${ }^{*} p<0.05,{ }^{* *} p<0.01$, ${ }^{* * *} \mathrm{p}<0.001$ vs control, Anova followed by Dunnett (REGWQ). CON = distilled water, DIAZ = diazepam $50 \mathrm{mg} / \mathrm{kg}$, THIO = sodium thiopental $50 \mathrm{mg} / \mathrm{kg}$.

Table 4 . The effects of the different plants on the total sleep time induced in mice by sodium thiopental or diazepam. 


\begin{tabular}{|c|c|c|c|c|c|c|c|}
\hline & & & & & & & \\
\hline Annona & & CON & 12 & 30 & 60 & 120 & $\mathrm{CP}$ \\
\hline \multirow{3}{*}{ Muricata } & PTZ & 0 & 16 & $50^{*}$ & 33 & $50 *$ & $100 * * *$ \\
\hline & STR & 0 & 12 & 0 & 12 & $50 *$ & $100 * * *$ \\
\hline & NMDA & 0 & 16 & 16 & 33 & $50^{*}$ & $100 * * *$ \\
\hline \multirow{2}{*}{$\begin{array}{l}\text { Annona } \\
\text { Senegalensis } \\
100^{* * *}\end{array}$} & & CON & 6.7 & 17 & 34 & 67 & $\mathrm{CP}$ \\
\hline & PTZ & 0 & 12 & 37 & $50^{*}$ & 25 & \\
\hline \multirow{4}{*}{$\begin{array}{l}\text { Bidens } \\
\text { pilosa }\end{array}$} & & CON & 14 & 35 & 70 & 140 & $\mathrm{CP}$ \\
\hline & PTZ & 0 & 16 & $50^{*}$ & 33 & $50^{*}$ & $100^{* * *}$ \\
\hline & STR & 0 & 16 & $50^{*}$ & 40 & $50^{*}$ & $100^{* * *}$ \\
\hline & NMDA & 0 & 33 & 33 & $66^{\star *}$ & $50 *$ & $100^{* * *}$ \\
\hline \multirow{4}{*}{$\begin{array}{l}\text { Bryophyllum } \\
\text { pinnatum }\end{array}$} & & CON & 28 & 70 & 140 & 280 & $\mathrm{CP}$ \\
\hline & PTZ & 0 & 16 & 33 & 16 & 33 & $100 * * *$ \\
\hline & STR & 0 & 0 & 10 & 0 & 16 & $100^{* * *}$ \\
\hline & NMDA & 0 & 33 & $50^{*}$ & $50^{*}$ & $50 *$ & $100^{* * *}$ \\
\hline \multirow{4}{*}{$\begin{array}{l}\text { Citrus } \\
\text { sinenis }\end{array}$} & & CON & 10 & 25 & 50 & 100 & $\mathrm{CP}$ \\
\hline & PTZ & 0 & 25 & 25 & 12 & 0 & $100^{* * *}$ \\
\hline & STR & 0 & 0 & 0 & 12 & 12 & $100^{* * *}$ \\
\hline & NMDA & 0 & $50^{*}$ & $50^{*}$ & $75^{\star *}$ & $75^{\star \star *}$ & $100^{* * *}$ \\
\hline \multirow{3}{*}{$\begin{array}{l}\text { Clerodendron } \\
\text { Thomsoniae }\end{array}$} & & $\mathrm{CON}$ & 13.4 & 33.5 & 67 & 134 & $\mathrm{CP}$ \\
\hline & PTZ & 0 & 12 & 37 & 37 & $62^{*}$ & $100^{* * *}$ \\
\hline & PIC & 0 & 0 & 25 & $50 *$ & $50 *$ & $100^{* * *}$ \\
\hline \multirow{3}{*}{$\begin{array}{l}\text { Daniellia } \\
\text { oliveri }\end{array}$} & & $\mathrm{CON}$ & 49.5 & 99 & 148.5 & 198 & $\mathrm{CP}$ \\
\hline & PTZ & 0 & 25 & 37 & 37 & $50^{*}$ & $100^{* * *}$ \\
\hline & STR & 0 & 16 & $66^{* *}$ & $50^{*}$ & $50^{*}$ & $100^{* * *}$ \\
\hline \multirow{3}{*}{$\begin{array}{l}\text { Detarium } \\
\text { microcarpum }\end{array}$} & & $\mathrm{CON}$ & 37 & 47 & 111 & 148 & $\mathrm{CP}$ \\
\hline & PTZ & 0 & $50^{*}$ & 37 & 0 & 0 & $100^{* * *}$ \\
\hline & STR & 0 & $50^{*}$ & 33 & 33 & 16 & $100^{* * *}$ \\
\hline \multirow{4}{*}{$\begin{array}{l}\text { Euphorbia } \\
\text { hirta }\end{array}$} & & $\mathrm{CON}$ & 14 & 35 & 70 & 140 & $\mathrm{CP}$ \\
\hline & PTZ & 0 & 0 & 25 & 0 & $50^{*}$ & $100^{* * *}$ \\
\hline & STR & 0 & 12 & 37 & 25 & 37 & $100^{* * *}$ \\
\hline & NMDA & 0 & 33 & 33 & $50^{*}$ & $50 *$ & $100^{* * *}$ \\
\hline \multirow{6}{*}{$\begin{array}{l}\text { Flacourtia } \\
\text { indica }\end{array}$} & & CON & 10 & 25 & 50 & 100 & $\mathrm{CP}$ \\
\hline & PTZ & 0 & $80^{* *}$ & $60^{*}$ & 40 & 40 & $100 * * *$ \\
\hline & STR & 0 & 20 & 40 & 40 & $60^{*}$ & $100 * * *$ \\
\hline & PIC & 0 & 40 & $60^{*}$ & $60^{*}$ & $80^{* *}$ & $100 * * *$ \\
\hline & MES & 0 & 40 & 0 & 0 & 40 & 100 \\
\hline & INH & $36 \pm 7$ & $48 \pm 5$ & $36 \pm 10$ & $50 \pm 12$ & $49 \pm 6$ & $73 \pm 11^{* * *}$ \\
\hline \multirow{3}{*}{$\begin{array}{l}\text { Hymenocardia } \\
\text { acida }\end{array}$} & & $\mathrm{CON}$ & 8.76 & 21.9 & 43.8 & 87.6 & $\mathrm{CP}$ \\
\hline & PTZ & 0 & 0 & 25 & 37 & $62^{*}$ & $100 * * *$ \\
\hline & STR & 0 & 16 & 33 & 33 & $50 *$ & $100 * * *$ \\
\hline \multirow{4}{*}{$\begin{array}{l}\text { Jatropha } \\
\text { gossypiifolia }\end{array}$} & & $\mathrm{CON}$ & 14 & 35 & 70 & 140 & $\mathrm{CP}$ \\
\hline & PTZ & 0 & 0 & 25 & 37 & 0 & $100^{* * *}$ \\
\hline & STR & 0 & $50^{*}$ & $50^{*}$ & $62^{*}$ & 25 & $100^{* * *}$ \\
\hline & PIC & 0 & 0 & 0 & 0 & 0 & $100^{* * *}$ \\
\hline \multirow{4}{*}{$\begin{array}{l}\text { Khaya } \\
\text { senegalensis }\end{array}$} & & $\mathrm{CON}$ & 6.7 & 17 & 34 & 67 & $\mathrm{CP}$ \\
\hline & PTZ & 0 & 12 & 12 & 0 & 25 & $100^{* \star *}$ \\
\hline & STR & 0 & 25 & $50^{*}$ & 25 & $50 *$ & $100^{* * *}$ \\
\hline & NMDA & 0 & $62^{*}$ & 33 & 33 & $50^{*}$ & $100^{* * *}$ \\
\hline \multirow{4}{*}{$\begin{array}{l}\text { Mentha } \\
\text { cordifolia }\end{array}$} & & CON & 14 & 35 & 70 & 140 & $\mathrm{CP}$ \\
\hline & PTZ & 0 & 16 & 33 & $66^{* *}$ & $50 *$ & $100 * * *$ \\
\hline & STR & 0 & 33 & 33 & 33 & $66^{* *}$ & $100 * * *$ \\
\hline & PIC & 0 & 16 & $50^{*}$ & 33 & $50 *$ & $100^{* * *}$ \\
\hline \multirow{3}{*}{$\begin{array}{l}\text { Prosopis } \\
\text { africana }\end{array}$} & & $\mathrm{CON}$ & 11.2 & 28 & 56 & 112 & $\mathrm{CP}$ \\
\hline & PTZ & 0 & 0 & 0 & 25 & 37 & $100^{* * *}$ \\
\hline & STR & 0 & $62^{*}$ & 25 & $50^{*}$ & $50^{*}$ & $100^{* * *}$ \\
\hline \multirow{2}{*}{$\begin{array}{l}\text { Ricinus } \\
\text { communis }\end{array}$} & & $\mathrm{CON}$ & 12 & 30 & 60 & 120 & $\mathrm{CP}$ \\
\hline & PTZ & 0 & 37 & $50^{*}$ & $62^{*}$ & $87^{\star \star *}$ & $100^{* * *}$ \\
\hline
\end{tabular}




\begin{tabular}{|c|c|c|c|c|c|c|c|}
\hline & INH & $31 \pm 9$ & $33 \pm 6$ & $36 \pm 8$ & $40 \pm 7$ & $56 \pm 16^{*}$ & $77 \pm 11^{* *}$ \\
\hline Securidaca & & CON & 10 & 20 & 50 & 66.7 & $\mathrm{CP}$ \\
\hline \multirow[t]{4}{*}{ longepedunculata } & PTZ & 0 & $67^{* *}$ & $67^{* *}$ & $83^{* * *}$ & $100^{* * *}$ & $100^{* * *}$ \\
\hline & STR & 0 & $50^{*}$ & $67^{* *}$ & $67^{* *}$ & $67^{* *}$ & $100^{* * *}$ \\
\hline & PIC & 0 & $67^{* *}$ & $100^{* * *}$ & $83^{* *}$ & $83^{\star *}$ & $100^{\star * *}$ \\
\hline & INH & $46 \pm 3$ & $51 \pm 5^{*}$ & $62 \pm 12^{* *}$ & $67 \pm 20^{* *}$ & \multicolumn{2}{|c|}{$78 \pm 21^{* *} 97 \pm 20^{* * *}$} \\
\hline Senna & & CON & 20 & 40 & 80 & 160 & $\mathrm{CP}$ \\
\hline \multirow{5}{*}{$\begin{array}{l}\text { senna } \\
\text { singueana }\end{array}$} & PTZ & 0 & $80^{* *}$ & $80^{* *}$ & 40 & 40 & $100^{* * *}$ \\
\hline & STR & 0 & $80^{* *}$ & $80^{* *}$ & 40 & 40 & $100^{* * *}$ \\
\hline & PIC & 0 & 20 & $60^{*}$ & 0 & 20 & $100^{* * *}$ \\
\hline & MES & 0 & 40 & 40 & 20 & 20 & $80^{* *}$ \\
\hline & INH & $21 \pm 1$ & $30 \pm 1^{* *}$ & $29 \pm 6$ & $32 \pm 9^{* *}$ & $37 \pm 1^{\star *}$ & $42 \pm 6^{\star *}$ \\
\hline Terminalia & & $\mathrm{CON}$ & 9.5 & 19 & 38 & 76 & $\mathrm{CP}$ \\
\hline \multirow{5}{*}{ glaucescens } & PTZ & 0 & 40 & $60^{*}$ & 40 & $100^{* * *}$ & $100^{* * *}$ \\
\hline & STR & 0 & 40 & 20 & 0 & 0 & $100^{* * *}$ \\
\hline & PIC & 0 & 20 & $60^{*}$ & 40 & 20 & $100^{* * *}$ \\
\hline & MES & 0 & 20 & 40 & 0 & 40 & $80^{* *}$ \\
\hline & INH & $36 \pm 7$ & $41 \pm 13$ & $18 \pm 5$ & $42 \pm 9$ & $47 \pm 13$ & $85 \pm 26^{* * *}$ \\
\hline Terminalia & & $\mathrm{CON}$ & 14 & 35 & 70 & 140 & $\mathrm{CP}$ \\
\hline \multirow{2}{*}{ mollis } & PTZ & 0 & $50^{*}$ & 37 & 25 & 37 & $100^{* * *}$ \\
\hline & STR & 0 & $66^{* *}$ & 33 & 33 & $50^{*}$ & $100^{* * *}$ \\
\hline \multirow{2}{*}{$\begin{array}{l}\text { Tetrapleura } \\
\text { tetraptera }\end{array}$} & & CON & 8.4 & 21 & 42 & 84 & $\mathrm{CP}$ \\
\hline & PTZ & 0 & 25 & $50^{*}$ & $50^{*}$ & $50^{*}$ & $100^{* * *}$ \\
\hline \multirow{3}{*}{$\begin{array}{l}\text { Trichilia } \\
\text { emetica }\end{array}$} & & CON & 12.6 & 33 & 66 & 126 & $\mathrm{CP}$ \\
\hline & PTZ & 0 & 25 & $50^{*}$ & $50^{*}$ & $50^{*}$ & $100^{* * *}$ \\
\hline & STR & 0 & 12 & 25 & $50^{*}$ & $50^{*}$ & $100^{* * *}$ \\
\hline \multirow{3}{*}{$\begin{array}{l}\text { Vitelaria } \\
\text { paradoxa }\end{array}$} & & CON & 12 & 21 & 42 & 84 & $\mathrm{CP}$ \\
\hline & PTZ & 0 & 12 & $50^{*}$ & $62^{*}$ & $50^{*}$ & $100^{* * *}$ \\
\hline & PIC & 0 & 0 & 12 & $50^{*}$ & 37 & $100^{* * *}$ \\
\hline
\end{tabular}

Data represent the percentage of protected mice in different tests. $\mathrm{N}=6$ or 8 per dose, ${ }^{*} \mathrm{p}<0.05$, ${ }^{* *} \mathrm{p}<0.01,{ }^{* * *} \mathrm{p}<0.001$ vs control, Anova followed by Dunnett (REGWQ). CON (negative control) $=$ distilled water, $\mathrm{CP}$ (positive control) = clonazepam $0.1 \mathrm{mg} / \mathrm{kg}$ for PTZ test, clonazepam $0.4 \mathrm{mg} / \mathrm{kg}$ for PIC test, clonazepam $3 \mathrm{mg} / \mathrm{kg}$ for STR test, diazepam $10 \mathrm{mg} / \mathrm{kg}$ for INH test and D-AP7 33 ๆmol/ $\mathrm{kg}$ or CGP $378493 \mathrm{mg} / \mathrm{kg}$ for NMDA test.

Table 5. The effects of the different plants on the convulsions and turning behaviour induced in mice by INH, NMDA, PIC, PTZ and STR.

mice against the induced convulsions. $78 \%$ of plants protected both PTZ and STR-induced convulsions. $80.6 \%$ of plants protected both PTZ and PIC-induced convulsions. $80.8 \%$ of plants protected both STR and PIC-induced convulsions. Finally, 66.7\% of plants at the same time protected PTZ, STR and PIC-induced convulsions.

\subsubsection{Plants toxicity}

Datura stramonium, Ricinus communis and Securidaca longepedunculata were also showed to be toxic. Their extract killed animal in $24 \mathrm{~h}$ after their administration to mice.

\section{Discussion and conclusions}

The extracts of twenty one plants (91.3\% of plants) increased the sleeping time induced by sodium thiopental or diazepam. The potentiation of the sleep time suggests the presence of sedative properties in the extracts of these plants (Rakotonirina et al., 2001; Ngo Bum et al., 2009a; 2009b). These sedative properties could be related to the presence of some components in the extracts activating the benzodiazepine, barbiturate and/or GABA 
receptors in the $\mathrm{GABA}_{\mathrm{A}}$ receptor complex (Rang et al., 1999; Bonin \& Orser, 2008; Olkkola \& Ahonen, 2008). Diazepam (benzodiazepine) and sodium thiopental (barbiturate) all bind to the $\mathrm{GABA}_{\mathrm{A}}$ receptor complex. Diazepam potentiates GABA-mediated inhibition via the increase in the affinity of this inhibitory neurotransmitter to its recognition sites within the $\mathrm{GABA}_{\mathrm{A}}$ receptor complex, by increasing the opening frequency of the chloride ion channel which leads to the enhancement of influx of chloride anions into the neuron and subsequent hyperpolarisation (Czapinsky et al., 2005). While sodium thiopental that act on the barbiturate binding site directly gate the chloride ion channel of the $\mathrm{GABA}_{\mathrm{A}}$ receptor complex. The sedative properties found here could explain the use of the twenty one plants in traditional medicine in Africa, particularly in Cameroon in the treatment of insomnia. The first eight more potent plants to induced sedation were: Datura stramonium $>$ Clerodendron thomsoniae $>$ Terminalia mollis $>$ Trichilia emetica $>$ Tetrapleura tétraptera $>$ Annona senegalensis $>$ Securidaca longepedunculata > Hymenocardia acida > Daniellia oliveri. Two plants, Citrus sinenis and Kaya senegalensis did not show sedative properties. The results also showed that 95.6\% of the tested plants possess anticonvulsant properties by inhibiting convulsions induced chemically or electrically. Five plants (Flacourtia indica, Ricinus communis, Securidaca longepedunculata, Senna singueana, Terminalia glaucescens) showed very good anticonvulsant activities against PTZ, PIC or INH induced seizures.

The effect was moderate for the rest of plants. Tetrapleura tetraptera one of the plants studied showed also anticonvulsant properties in fruits (Nwaiwu, 1986; Ojewole, 2005). The antagonism of INH, PTZ- and PIC-induced seizures suggests the interaction of these plants with the GABA-ergic neurotransmission (De Deyn et al., 1992; Doctor et al., 1982; Löscher \& Schmidt, 1988; Salih \& Mustafa, 2008; Perez-Saad \& Buznego, 2008). GABA is the main inhibitory neurotransmitter substance in the brain and is widely implicated in epilepsy. Inhibition of GABA-ergic neurotransmission or activity has been shown to promote and facilitate seizures, while enhancement of GABA-ergic neurotransmission is known to inhibit or attenuate seizures (Gale, 1992; Li-Ping et al., 2008). Moreover, some studies indicated that PTZ diminishes the GABAergic tone (Mcdonald \& Baker. 1977; Ahmadiani, 2003), probably by a competitive antagonist action on the BZD receptors (Rehavi et al., 1982). Correspondingly, drugs that enhance $\mathrm{GABA}_{\mathrm{A}}$-receptor neurotransmission, such as BZDs (White, 1997; Ahmadiani et al., 2003) can block seizures induced by PTZ. PIC is known to be a non competitive GABA antagonist exerting his effect by blocking the chloride channel in the $\mathrm{GABA}_{\mathrm{A}}$ receptor complex. Isoniazide can precipitate convulsions in patients with seizure disorders, and it is regarded as a GABA-synthesis inhibitor (Kale Shubhangi et al., 2010). The antagonism of STR -induced convulsions suggests the presence of anticonvulsant effect through glycine-STR-sensitive receptors (Findlay et al., 2002). Few plants extract antatagonized MES induced convulsions, by probably prolonging neurons sodium channels inactivation (Holmes, 2007). The results show no difference in plants inhibiting convulsions induced by PTZ, PIC and STR. GABA and glycine-STR-sensitive neurotransmission are equally involved. But very few plants produced their anticonvulsant activities by prolonging neurons sodium channels inactivation. Datura stramonium, Ricinus communis and Securidaca longepedunculata were found toxic and therefore they are not suitable to be used to treat people. The toxicity of Ricinus communis could be related to the presence of a very toxic component named ricin (Iwu, 1993). The toxicity of Datura stramonium could be related to its delirants or anticholinergics compounds. 


\section{Conclusion}

The purported anticonvulsant and sedative properties of the medicinal plants are scientifically shown. The ethnopharmacological study on Cameroon anticonvulsant and sedative medicinal plants is accurate in $90 \%$ of cases. A great amount of plants extract interacted through GABA and glycine-STR-sensitive neurotransmissions to inhibit convulsions. Many anticonvulsant plants also possess sedative properties. Twenty one plants possess sedative properties, but only eighteen plants could be used in traditional medicine in Africa in the treatment of insomnia. Eighteen plants possess at least moderate anticonvulsant effects, while five plants possess very good anticonvulsant properties. However only twenty medicinal plants could be used in the treatment of epilepsy. Three plants were found very toxic.

\section{Acknowledgment}

We would like to thank Professor AMVAM ZOLLO Paul Henri, Professor Ngounouno Ismaila, and Dr Megueni Clautilde for their support.

\section{References}

Abbiw, D. K. (1990). Useful plants of Ghana: West African uses of wild and cultivated plants. ISBN 185390437, London, United Kingdom.

Adeyemi, O.O.; Akindele, A.J.; Yemitan, O.K.; Aigbe, F.R. \& Fagbo, F.I. (2010). Anticonvulsant, anxiolytic and sedative activities of the aqueous root extract of Securidaca longepedunculata Fresen. Journal of Ethnopharmacology, Vol.130, No.2, (July, 2010), pp. 191-195, ISSN 0378-8741.

Adjanohoun, J.E.; Ake Assi, L.; Chibon, P.; De Vecchy, H.; Duboze, E.; Eyme, J.; Gassita, J.N.; Goudote, E.; Guinko, S.; Keita, A.; Koudogbo, B.; Le Bras, M.; Mourambou, I.; MveMengome, E.; Nguema, M.G.; Ollome, J.B.; Posso, P. \& Sita, P. (1984). Médecine traditionnelle et pharmacopée: contribution aux études ethnobotaniques et floristiques $d u$ Gabon. Editions A.C.C.T. ISBN 0754-0924, Paris, France.

Adjanohoun, J.E.; Aboubakar, N.; Dramane, K.; Ebot, M.E.; Ekpere, J.A.; Enow- Orok, E.G.; Focho, D.; Gbile, Z.O.; Kamanyi, A.; Kamsu-kom, J.; Keita, A.; Mbenkum, T.; Mbi, C.N.; Mbiele, A.L.; Mbome, L.L.; Mubiru, N.K.; Nancy, W.L.; Nkongmeneck, B.; Satabie, B.; Sofowora, A.; Tamze, V. \& Wirmum, C.K. (1996). Traditional medicine and pharmacopoeia: Contribution to ethnobotanical and floristic studies in Cameroon. Organization of African Unity Scientific, Technical and Research Commission; Centre National de Production de Manuels Scolaires, ISBN 0716-084, Porto-Novo, Benin.

Adzu, B.; Abbah, J.; Vongtau, H. \& Karniyus . (2003). Studies on the use of Cassia singueana in malaria ethnopharmacy, Journal of Ethonopharmacology, Vol.88, No.2-3, (October 2003), pp. 261-267, ISSN: 0378-8741.

Agassounon Djipko Tchibozo, M.; Sanon, S.; Damintoti, S.K.; Toukourou, F.; de Souza, C., Gbeassor, M., (2008). Appréciation des propriétés antiplasmodiale in vitro de Flacourtia flavescens Willd., une plante utilisée dans la médecine traditionnelle en Afrique. 15ème colloque sur la Pharmacopée et la Médecine Traditionnelles Africaines. Vol.15, pp. 156-160. (Décembre 2008), Conseil Africain et Malgache pour l'Enseignement Supérieur (CAMES), Libreville, Gabon. 
Ahmadiani, A.; Mandgary, A. \& Sayyah, M. (2003). Anticonvulsivant Effect of Flutamide on seizures induiced by pentylene tetrazole, involvement of benzodiazepine receptors. Epilepsia, Vol.44, No.5, (May 2003), pp. 629-625, ISSN 1528-1167.

Anete, C.F.; Miriam, E.M. A.; Da Costa, M.L.; Ilza, R.B.; Bras ,H.D.O. \& Cunha, C.D. (1998). Pharmacological Evaluation of Ricinine, a Central Nervous System Stimulant Isolated from Ricinus communis. Pharmacology, Biochemestry and Behavior, Vol.63, No.3, (November 1998), pp. 367-375, ISSN 0091-3057.

Anuradha1, H.; Srikumar, B.N.; Shankaranarayana, Rao, B.S. \& Lakshmana, M. (2008). Euphorbia hirta reverses chronic stress-induced anxiety and mediates its action through the GABAA receptor benzodiazepine receptor- $\mathrm{Cl} 2$ channel complex. Journal of Neural transmission, Vol.11, No 3, (September 2008), pp. 35-42, ISSN 1435-1463.

Arbonnier, M. (2000). Arbres, arbustes et lianes des zones sèches d'Afrique de l'Ouest. Mali, Ouagadougou: Centre de Coopération Internationale en Recherche Agronomique pour le développement/Muséum national d'histoire naturelle/Union mondiale pour la nature (CIRAD/MNHN/UICN), IBSN 0209-0914, Paris, France.

Beretz, A.; Haag-Berrurier, M.; Anton, R. (1978). Choix de méthodes pharmacologiques pour l'étude des activités de l'aubépine. Plantes médicinales et phytothérapie , Vol .4, pp. 305314.

Berhaut, J. (1975). Flore illustrée du Sénégal. Dicotylédones. Tome IV Ficoidées à Légumineuses. Government of Senegal, pp. 183-184, 553-555, Dakar, Senegal.

Bernasconi, R.; Klein, M.; Martin, P.; Christen, P.; Hafner, T.; Portet, C. \& Schmutz, M. (1988). Gamma-Vinyl GABA: comparison of neurochemical and anticonvulsant effects in mice. Journal of Neural Transmission, Vol.72, No.3, (October 1988), pp. 213233, ISSN 1435-1463.

Biholong, M. (1986). Contribution à l'étude de la flore du Cameroun: les Astéracées. Thèse de doctorat. Université de Bordeaux III, pp. 10-50, France.

Bonin, R.P. \& Orser, B.A. (2008). GABA $\mathrm{A}_{\mathrm{A}}$ receptor subtypes underlying general anesthesia. Pharmacology Biochemistry and Behavior, Vol.90, No.1, (January 2008), pp. 105-112, ISSN 0091-3057.

Bouquet, A. (1969). Féticheurs et Médecine Traditionnelle au Congo (Brazaville). ORSTOM, IRD, FDI 13972, Mémoire No. 36, pp. 103-127, Montpellier, France.

Boussinesq, M.; Pion, D.S. \& Kamgno, J. (2002). Relationship between Onchocerciasis and epilepsy: a matched case control in the Mbam Valley, Republic of Cameroon. Transaction of the Royal Society of Tropical Medicine and Hygiene, Vol.96, No.5, (September 2002), pp. 537-541, ISSN 0035-9203.

Brenan J.P.M. (1959). Légumineuses (I) sous-famille des Caesalpinioidea dans Flore de l'Afrique orientale tropicale. Agents de la Couronne, Londres, England.

Croucher, J.M.; Collins, J.F. \& Meldrum, B.S. (1982). Anticonvulsant action of excitatory amino acids antagonists. Science, Vol. 216, No. 4548, (May 1982), pp. 899-902, ISSN 1095-9203.

Czapinski, P.; Blaszczyk, B. \& Czuczwar, S.J. (2005). Mechanisms of Action of Antiepileptic Drugs. Current Topics in Medicinal Chemistry, Vol.5, No.1, (January 2005), pp. 3-143, ISSN 1568-0266.

Dalziel, J.M. (1937). The useful plants of West Tropical Africa. The Crown Agency for the Colonies, London, United Kingdom. 
De Deyn, P.P.; D’Hooge, R.; Marescau, B. \& Pei, Y-Q. (1992). Chemical models of epilepsy with some reference to their applicability in the development of anticonvulsants. Epilepsy Research, Vol.12, No.2, (July 1992), pp. 87-110, ISSN 0920-1211.

Dimo, T.; Rakotonirina, S.V.; Tan, P.V.; Azay, J.; Dongo, E. \& Cros, G. (2002). Leaf methanol extract of Bidens pilosa prevents and attenuates the hypertension induced by highfructose diet in wistar rats. Journal of Ethnopharmacology, Vol.83, No. 4, (June 2002), pp. 183-191, ISSN 0378-8741.

Diop, A.G.; Ndiaye, M.; Thiam, A.; et al. (1996). Filière des soins anti-épileptiques en Afrique. Epilepsies, Vol. 10, pp.115-121.

Doctor, S.V.; Costa, L.G. \& Muphur, S.D. (1982). Effect of trimethyltin on chemically induced seizures, Toxicology Letters, Vol.13, No.4, (October 1982), pp. 217-223, ISSN 0378-4274

Dongmo, L.; Ndo, D.; Atchou,G. \& Njamnshi, A. (2000). Epilepsie au Sud-Cameroun: enquête préliminaire dans le village Bilomo. Bulletin de la Société de Pathologie Exotique, Vol.93, No.3, (July 2000), pp. 263-275, ISSN 0037-9085.

Dongmo, L.; Druet-Cabanac, M.; Moyou, S.R.; Zebaze, D.R.; Njamn-shi, A.K.; Sini, V.; Mapoure, N.; Echouffo, T.J.; Djeumen, W.C. \& Ndumbe, P.M. (2004). Cysicercosis and epilepsy: a casec ontrol study in MbamValley, Cameroon. Bulletin de la Société de Pathologie Exotique, Vol. 97, No. 2, (Janvier 2003), p. 105-108, ISSN 0037-9085.

El-Mahmood, A. M; Doughari, J.H. \& Ladan, N. (2008). Antimicrobial screening of stem bark extracts of Vitellaria paradoxa against some enteric pathogenic microorganisms. African Journal of Pharmacy and Pharmacology, Vol. 2, No. 5, (July 2008), pp. 089-094, ISSN: 1996-0816.

Ezugwu, C.O. \& Odoh, U.E. (2003). Anticonvulsant activity of the root extract of Annona senegalensis. Journal of Tropical Medicinal Plants, Vol.4, No.1, (July 2003), pp. 51-55, ISSN 1511-8525.

Findlay, G.S.; Wick, M.J.; Mascia, M.P.; Wallace, D; Millier, G.W.; Harris, R.A. \& Blednov Y.A. (2002). Transgenic expression of a mutant glycine receptor decreases alcohol sensitivity of mice. Journal Pharmacology Experimental Therapeutics, Vol. 300, No. 2, (February 2002), pp. 526-534, ISSN 0022-3565.

Gale K. (1992). GABA and epilepsy: basic concepts from preclinical research. Epelepsia. Vol.33, No.5, (November 1992), pp. S3-S12, ISSN 0013-9580.

Geoffrey, C. \& Kirby, M. (1996). Medicinal plants and the control of protozoa disease with particular reference to malaria. Transaction of the Royal Society of Tropical Medicine and Hygiene, ISSN 0035-9203, London, Great Britain.

Gusman-Gutierez, S.L. \& Navarrete A. (2009). Pharmacological Exploration of the sedative mechanism of hesperidin identified as the Active principle of Citrus sinensis flowers. Planta medica, Vol. 75, No. 4, (February 2009), pp. 295-301, ISSN: 0032-0943.

Holmes, G.L. (2007). Animal model studies application to human patients. Neurology, Vol. 69, No.24, (December 2007), pp. S28-S32, ISSN 0028-3878.

Hutchinson, J. \& Dalziel, J.M. (1958). Flora of West Tropical Africa. Crown Agents, Ed. 2 (Revised by R.W.J. Keay), The Whitefriars Press, London \& Tonbridge, Great Britain.

Iwu, M.M. (1993). Handbook of African Medicinal Plants. CRC Press, ISBN 084934266X, New York, USA.

Kale Shubhangi, S.; Shete Rajkumar, V.; Kore Kakasaheb, J.; Patil Bhaskar, M.; Bhutada Rupesh, N.; Pattankude Vinod, (2010). Anticonvulsant activity of Glycyrrhizic acid in 
mice. International journal of pharmaceutical researches and development, Vol.2, No.2, (December 2010), ISSN 0974 - 9446

Kamgno,J.; Pion,S. \& Boussinesq, M. (2003). Demographic impact of epilepsy in Africa: results of a 10-years cohort study in a rural area of Cameroon. Epilepsia, Vol. 44, No7, (July 2003), pp. 956-963, ISSN 0013-9580.

Lehmann, J.; Hutchison, A.; McPherson, S.E.; Mondadori, C.; Schmutz, M.; Sinton, C.M.; Tsai, C.; Murphy, D.E.; Steel, D.J.; Williams, M.; Cheney, D.L. \& Wood, P.L. (1988). CGS 19755, a selective and competitive N-methyl-D-aspartate-type excitatory amino acid receptor antagonist. Journal of Pharmacology and Experimental Therapeutics Vol.246, No.1, (July 1988), pp. 65-75, ISSN 1521-0103.

Li-Ping, G.; Xian-Yu, S.; Guan-Rong, T.; Kyu-Yun, C. \& Zhe-Shan, Q. (2008). The Synthesis and Anticonvulsant Activity of 1-Substituted-7-Methoxy-1,2,4-Triazolo [4, 3-a] Quinoline; Turkish journal of chemistry, Vol.32, No.2, (April 2008), pp. 181-189, ISSN 1300-0837.

Lompo, M.; Nikiema, J.B.; Guissou, I.P.; Moës, A.J. \& Fontaine, J. (1998). The topical antiinflammatory effects of chloroform extract from Khaya senegalensis stem barks. Phytotherapy Research, Vol.12, No.6, (July 1998), pp. 448-450, ISSN: 0951-418X.

Löscher, W. \& Schmidt, D. (1988). Which animal model should be used in the search for new antiepileptic drugs? A proposal based on the experimental and chemical consideration. Epilepsy Research, Vol. 2, No. 3, (May 1988), pp. 145 -181, ISSN 09201211.

Macdonald, R.L. \& Barker, J.L. (1977). Pentylenetetrazole and penicillin are selective antagonists of GABA-mediated post-synaptic inhibition in cultured mammalian neurons. Nature, Vol.267, No.23, (June 1977), pp. 720-721, ISSN 0028-0836.

Malgras, D. (1992). Arbres et arbustes guérisseurs des savanes maliennes. ACCT, Karthala, ISBN 2865373770, Paris, France.

Mutasa, S.L.; Khan, M. \& Jewers, K. (1990). 7-Methylphyscion and cassiamin A from the root bark of Cassia singueana. Planta Medica. Vol.56, No.2, (April 1990) pp. 244-245, ISSN 0032-0943.

Nazneen, M.; Abdul Mazid; Kundu, J.K.; Bachar, S.C.; Begum, F. \& Datta, B.K. (2009). Protective effects of Flacourtia indica aerial parts extracts against paracetamol-induced hepatotoxicity in rats. Journal of Taibbah University for Science. Vol.2, No.1, (January 2009), pp. 1-6, ISSN 1658-3655.

Nchoji Nkwi,P. \& TiokoNdonko, F. (1989). The Epileptic among the Bamileke of Maham in the Nde Division, West Province of Cameroon. Culture Medicine and Psychiatry, Vol.13, No.4, pp. 437-448, ISSN 0165-005X.

Ngo Bum, E.; Schmutz, M.; Meyer, C.; Rakotonirina, A.; Bopelet, M.; Portet, C.; Jeker, A.; Rakotonirina, S.V.; Olpe, H.R. \& Herrling, P. (2001). Anticonvulsant properties of the methanolic extract of Cyperus articulatus (Cyperaceae). Journal of Ethnopharmacology Vol.76, No.2, (July 2001), pp. 145-150, ISSN: 0378-8741.

Ngo Bum, E.; Taiwe, G.S.; Nkaissa, L.A.; Moto, F.C.O.; Seke, E.P.F.; Hiana, I.R.; Bailabar, T.; Rouyatou; Seyni, P.; Rakotonirina, A. \& Rakotonirina, S.V. (2009a). Validation of anticonvulsant and sedative activity of six medicinal plants. Epilepsy and Behavior, Vol.14, No.3, (March 2009), pp. 454-458, ISSN 1525-5050.

Ngo Bum, E.; Taiwe G.S.; Moto F.C.O.; Ngoupaye G.T.; Nkantchoua G.C.N.; Pelanken M.M.; Rakotonirina S.V. \& Rakotonirina A. (2009b). Anticonvulsant, anxiolytic and sedative 
properties of the roots of Nauclea latifolia Smith in mice. Epilepsy and Behavior, Vol. 15, No. 4, (August 2009), pp. 434-440, ISSN 1525-5050.

Ngounou, E.B.; Quet, F.; Dubreuil, C.M.; Marin, B.; Houinato, D.; Nubukpo, P.; Dalmay, F.; Millogo, A.; Nsengiyumva, G.; Kouna-Ndouongo, P.; Diagana, M.; Ratsimbazafy, V.; Druet-Cabanac, M. \& Preux, P.M. (2007). Épidémiologie de l'épilepsie en Afrique subsaharienne : une revue de la littérature. Cahiers d'études et de recherche francophones/Santé. Vol.16, No.4, (Octobre-novembre-décembre 2006), pp. 225-238, Synthèse.

Njamnshi, A.K.; Bissek, A.C.; Yepnjio, F.N. ; Tabah, E.N.; Angwafor, S.A.; Kuate, C.T.; Déma, F.; Fonsah, J.Y.; Acho, A.; Kepeden, M.N.; Azinwi, Y.H.; Kuwoh, P.B.; Angwafor III, F.F. \& Muna, W.F. (2010). A community survey of knowledge, perceptions, and practice with respect to epilepsy among traditional healers in the Batibo Health District, Cameroon. Epilepsy and behavior, Vol. 17, N¹1, (January 2010), pp.95-102, PMID: 19932640.

Nwaiwu, J.I. \& Akah, P.A. (1986). Anticonvulsant activity of the volatile oil from the fruit of tetrapleura tetraptera. Journal of Ethnopharmacology Vol.18, No.2, (July 1982), pp. 103107, ISSN: 0378-8741.

Ogundiya, M. O.; Kolapo, A. L.; Okunade, M. B.; Adjumobi, J. A. (2009). Assesment of phytochemical composition and antimicrobial activity of Terminalia glaucescens against some oral pathogens. Electronic journal of environmental, agricultural and food chemistry; Vol.8, No.7, (January 2009), pp. 466-471, ISSN: 1579-4377.

Ojewole, J.A. (2005). Analgesic and anticonvulsant properties of Tetrapleura tetraptera (Taub) (Fabaceae) fruit aqueous extract in mice. Phytotherapy Research, Vol.19, No.12, (December 2005) pp. 1023-1029, ISSN 1099-1573.

Okada, R. \& Negishi, H. (1989). The role of nitrotegmental gabaergic pathway in the propagation of pentylenetetrazol-induced seizures. Brain Research. Vol.480, No.1, (February 1989), pp. 383-387, ISSN 0006-8993.

Olkkola, K.T. \& Ahonen, J. (2008). Midazolam and other benzodiazepines. Handbook of Experimental Pharmacology, Vol.182, No.1, (January 2001), pp. 335-360, ISSN: 03788741.

Palgrave, C.K.; Drumond, R.B.; Eugene, J. \& Palgrave, C.M. (2003). Trees of Southern Africa. Struik Publishers, ISBN 1868723895, Cape Town South Africa.

Pathak, P.; Saraswathy, Vora, A. \& Savai J. (2010). In vitro antimicrobial activity and phytochemical analysis of the leaves of Annona muricata. International Journal of Pharmaceutical Researches and Development, Vol.2, No.5, (July 2010), pp. 1-6, ISSN: 09749446.

Pérez-Saad, H. \& M.T. Buznego (2008). Behavioral and antiepileptic effects of acute administration of the extract of the plant Cestrum nocturnum Lin (lady of the night). Epilepsy and Behaviour, Vol.12, No.3, (April 2008), pp. 366-372, ISSN 1525-5050.

Pousset, J.L. 1989. Plantes médicinales africaines, utilisation pratique. Ellipses, ISBN 2729889183, Paris, France.

Preux, P.M.; Tiemagni,F.; Fodzo,L.; Kandem,P.; Ngouafong, P.; Ndonko,F.; Macharia,W.; Dongmo, L.; Dumas,M. (2000). Antiepileptic therapies in the Mi Province in Cameroon. Epilepsia, Vol.41, No.4. (April 2000), pp. 432-439, ISSN 1528-1167.

Prischich, F.; De Rinaldis, M.; , Flaminia, B.; Egeo, G.; Santori, C.; Zappaterreno, A.; Fattouch, J.; Di Bonaventura, C.; Bada, J.; Gianluca, R.; Pizzuti, A.; Cardona, F.; Sa'a, 
V.V.; Giallonardo, A.T.; D’Erasmo, E.; Pelliccia, A. \& Vanacore, N. (2008). High prevalence of epilepsy in a village in littoral province of Cameroon. Epilepsy Research, Vol. 82, No. 2, (October 2008), pp. 200-210, ISSN 0920-1211.

Rakotonirina, S.V.; Ngo Bum, E.; Rakotonirina, A. \& Bopelet, M. (2001). Sedative properties of the extract of the rhizome of Cyperus articulatus. Fitoterapia, Vol.72, No.1, (September 2001), pp. 22-29, ISSN 0367-0326.

Rang, H.P., Dale, M.M., Ritter, J.M., 1999. Pharmacology. Churchill Livingstone, ISBN 0443059748, New York, USA.

Raponda-Walker, Sillans, R. (1961). Les plantes utiles du Gabon. Edition Sepia, ISBN 2907888692, Libreville, Gabon.

Rehavi, M.; Skolnick, P. \& Paul, .S.M. (1982). Effects of tetrazole derivatives on [3H]diazepam binding: in vitro: correlation with convulsant potency. European Journal of Pharmacoly, Vol.78, No.3, (March 1982), pp. 353-356, ISSN 0014-2999.

Salih, M.A. \& Mustafa, M.M. (2008). A substance in broad beans (Vicia faba) is protective against experimentally induced convulsions in mice. Epilepsy and Behaviour, Vol. 12, No. 1, (January 2008), pp. 25-29, ISSN 1525-5050.

Satyanaraya, V.; Kurupadanam, G.L. \& Srimanaraya, G. (1996). Photochemistry of plants. Fitoterapia. Vol.30, No.4, (July 1996), pp. 1026-1029, ISSN 0367-326X.

Saulnier, P. (1998). Plantes médicinales et soins en Afrique, Edition SEPIA, ISBN : 9782907888929, Saint-Maur, France.

Schmutz, M.; Portet, C.; Jeker, A.; Klebs, K.; Vassout, A.; Allgeier, H.; Heckendorn, R.; Fagg, G.E.; Olpe, H.R. \& Van Riezen, H. (1990). The competitive NMDA receptor antagonists CGP 37849 and CGP 39551 are potent, orally-active anticonvulsants in rodents. Naunyn-Schmiedeberg's Archives of Pharmacology, Vol.342, No.7, (October 1990), pp. 61-66, ISSN 1432-1912.

Seema, Z. (2006). Phytochemical studies on Terminalia glaucescens, Pteleopsis hylodendron and related medical plants. Thèse doctorat Ph.D., Université de Karachi, Pakistan.

Sunday, E.; Atawodi, \& Ogunbusola, F. (2009). Evaluation of Anti trypanosomal Properties of Four Extracts of Leaves, Stem and Root Barks of Prosopis africana in Laboratory Animals. Nigerian for experimental biology Vol.21, No.2, (December 2009), pp. 101-108, ISSN 0795-8080

White, H.S. (1997). New mechanisms of antiepileptic drugs, In: Porter, R., Chadwick, D., (Ed.), 1-30, Butterworth Heinemann, ISBN 1933864168, Boston, USA.

Worapan, S.; Sornkanok, V.; Chuda, C.; Damri, P. \& Siriprapa, A. (2008). Pharmacognostic Investigation of the Leaves of Mentha cordifolia and its DNA Fingerprints. Thai Pharmaceutical and Health Science Journal, Vol. 4, No. 1, (January 2009), pp.9-14. ISSN: 0125-4685. 


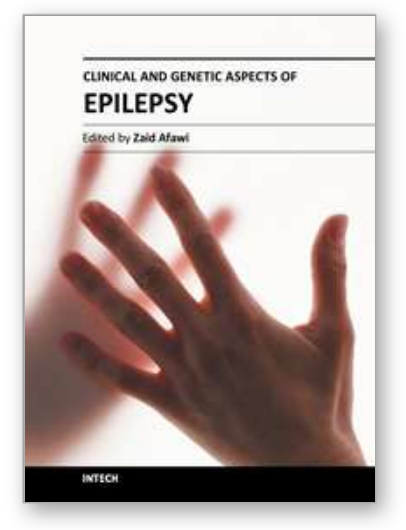

\author{
Clinical and Genetic Aspects of Epilepsy \\ Edited by Dr. Zaid Afawi
}

ISBN 978-953-307-700-0

Hard cover, 204 pages

Publisher Intech

Published online 15, September, 2011

Published in print edition September, 2011

This book on Epilepsy was conceived and produced as a source of information on wide range of issues in epilepsy. We hope that it will help health care providers in daily practices and increase their understanding on diagnosis and treatment of epilepsies. The book was designed as an update for neuroscientists who are interested in epilepsy, primary care physicians and students in health care professions.

\title{
How to reference
}

In order to correctly reference this scholarly work, feel free to copy and paste the following:

E. Ngo Bum, G.S. Taiwe, F.C.O. Moto, G.T. Ngoupaye, R.R.N. Vougat, V.D. Sakoue, C. Gwa, E.R. Ayissi, C. Dong, A. Rakotonirina and S.V. Rakotonirina (2011). Antiepileptic Medicinal Plants used in Traditional Medicine to Treat Epilepsy, Clinical and Genetic Aspects of Epilepsy, Dr. Zaid Afawi (Ed.), ISBN: 978-953-307-700-0, InTech, Available from: http://www.intechopen.com/books/clinical-and-genetic-aspects-ofepilepsy/antiepileptic-medicinal-plants-used-in-traditional-medicine-to-treat-epilepsy

\section{INTECH}

open science | open minds

\author{
InTech Europe \\ University Campus STeP Ri \\ Slavka Krautzeka 83/A \\ 51000 Rijeka, Croatia \\ Phone: +385 (51) 770447 \\ Fax: +385 (51) 686166 \\ www.intechopen.com
}

\author{
InTech China \\ Unit 405, Office Block, Hotel Equatorial Shanghai \\ No.65, Yan An Road (West), Shanghai, 200040, China \\ 中国上海市延安西路65号上海国际贵都大饭店办公楼 405 单元 \\ Phone: +86-21-62489820 \\ Fax: +86-21-62489821
}


(C) 2011 The Author(s). Licensee IntechOpen. This chapter is distributed under the terms of the Creative Commons Attribution-NonCommercialShareAlike-3.0 License, which permits use, distribution and reproduction for non-commercial purposes, provided the original is properly cited and derivative works building on this content are distributed under the same license. 